Environment, Biodiversity \& Soil Security
(EBSS)

\title{
Influence of Arbuscular Mycorrhizal Fungi (AMF) Inoculation on the Performance of Sakha 107 Rice Cultivar under Different Irrigation Intervals
}

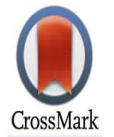

\section{E.E. Gewaily}

Rice Research \& Training Center, Field Crops Research Institute, Agricultural Research Center, Sakha, Kafr El Sheikh, Egypt.

$\mathbf{T}$ HE EXPERIMENT was performed at the experimental farm of Sakha Agricultural Research Station, Rice Research Section, Kafr El-Sheikh, Egypt for two growing seasons (2017 and 2018) to determine the performance of Sakha 107 rice cultivar due to the inoculation with Arbuscular Mycorrhizal fungi (AMF) under different irrigation intervals. The experiment was carried out in a split plot design with three replications. Irrigation treatments (continuous flooding (I1), irrigation every 6 (I2), 9 (I3) and 12 days (I4)) considered as the main plots. However, the sub plots were occupied by two levels of inoculation of AMF, control (M1) and inoculation seeds in nursery bed by $1.2 \mathrm{~kg} \mathrm{ha}^{-1}$ (M2). Results revealed that growth, grain yield and its attributes of Sakha 107 rice cultivar, as well as $\mathrm{N}$ and $\mathrm{P}$ uptake by grain were significantly influenced by irrigation treatments in both seasons. I1 treatment gave the highest values, followed by I 2 treatment, whereas I4 treatment recorded the lowest values. The M2 treatment increased the previous parameters as compared to M1 treatment. The average reductions in grain yield were found to be $3.48,14.96$ and $24.59 \%$ with corresponding values of water saved of $6.62,12.46$ and $25.00 \%$ when the interval period was prolonged up to 6 , 9 and 12-day, respectively. I2 treatment gave the highest values of productivity of irrigation water (PIW) followed by I4 treatment. Inoculation by AMF under any of irrigation treatments resulted in increase the PIW. Where, the combination of M2 treatment with I2 and I4 treatments gave the maximum values of PIW. Results showed the importance of mycorrhiza of rice plant under drought stress conditions.

Keywords: Arbuscular Mycorrhiza, Irrigation intervals, Rice, Yield.

\section{Introduction}

In Egypt, considerable national breeding attempts have been exerted to improve suitable and agreeable rice cultivars for the different production ecosystems. Raising rice production through developing the varieties persist to remain a big challenge, particularly with limiting areas and irrigation water. However, irrigation water is relatively limited and insufficient for both reclamation and irrigation purposes for Egyptian soil. So, it is essential to identify rice production systems that need a lesser amount of irrigation water with minimum grain yield reduction. Total seasonal water input to rice fields varies among cultivars according to plant duration and canopy. However, the accession of rice cultivars is likely to vary under continuous flooding conditions and it may also vary with the quantity of water needed. Cultivars that can sustain water intake under shortage of soil water content may produce larger increment of grain yield and these cultivars will become considered as the water supply decreases. Now, water is becoming insufficient in many countries,(El-Refaee et al., 2011).

The enhancement of rice production still demands as a result of the steady increase in

Corresponding author e-mail: sgewaily@yahoo.com

Received 4/8/2019; Accepted 8/9/2019

DOI: $10.21608 / J E N V B S .2019 .15637 .1068$

(C)2019 National Information and Documentation Center (NIDOC) 
population of world. The population of world is expected get to about eight billion in 2030 and there is a necessity for extra increase in productivity of rice by for typercent then twenty years (Bernier et al., 2008). One promising manner for raising productivity of rice is to improve yield and tolerance to stresses by employment the rhizosphere microbial manipulation. The microbial groups such as plant growth promoting rhizobacteria (PGPR) and AM fungi can enhance development of agricultural (Barea et al., 2005). Inoculation by PGPR and AM fungi has been desired as an effective method for improve growth of plant (Azcón and Barea, 2010). Synergistic influences were exhibited on growth of plant mainly when AM fungi are inoculated under growth limited conditions (Vivas et al., 2003). AMF simplify water and nutrients uptake by plant from soil interphase. However, the plant provides carbon for fungus, which employs for its growth, progress, and other physiological performance (Panneerselvam et al., 2017).

Around fifty percent of rice fields in the world do not receive enough quantity of irrigation water to sustain submerged conditions, for that production is decreased to some extent by water deficit. Water shortage at critical growth periods might cause significant reduction in rice productivity. Therefore, existed a necessity for wise management of irrigation water for sustain rice production. AMF inoculation symbiotically combined with plant roots can be achieved and keep up this sustainability to raise plant water acquisition, enhancing plant growth and crop yield under water deficit conditions (Barea et al. 2005 and Azcón and Barea, 2010).

Keeping up or rising rice yield with the shortage of water quantity which used in rice production is becoming a big challenge for recent sustainable rice productivity. On the other hand, rice plant has relatively scarce adjustments to deficiency of irrigation water and it is very susceptible to water shortage stress (Kamoshita et al., 2008). Inoculation by helpful microorganisms can increase plant water acquisition and tolerance of water stress. Soil microbes such as AMF symbiotically associated with roots of plant can improve a series of activities to enhance plant growth and yield production under water deficit conditions (Barea et al., 2005 and Azcón and Barea, 2010). Ruiz-Sánchez et al. (2010) stated that AMF (Glomusintraradices) increased growth response, photosynthetic efficiency, and antioxidative responses of rice plant toward water deficit strain. Apply the AMF in nursery bed increased rice grain yield by $14-21 \%$ (Solaiman and Hirata 1997).

Secilia and Bagyaraj (1994) stated that in wetland, inoculation rice plant with Acaulospora sp., Glomus fasciculatum, and G. mosseae enhanced rice grain yield by 35-62\%. (Barea, 1991) stated that AMF (Glomusetunicatum) exhibited fairly high colonization in rice roots and best survival under submerged conditions.

Wetness strain is a main limiting factor in crop production. Achievement highest grain yield per irrigation water (productivity of irrigation water) is a most important goal under inadequate water availability. In this respect, AMF plays an important role in protecting plant contrary to osmotic.

Consequently, this study was aimed to explore the impact of Arbuscular Mycorrhizal fungi inoculation on performance of Sakha 107 rice cultivar, nutrients ( $\mathrm{N}$ and $\mathrm{P}$ ) uptake and productivity of irrigation water (PIW) under different irrigation intervals.

\section{Materials and Methods}

A field experiment was performed at the experimental farm of Sakha Agricultural Research Station, Rice Research Section, Kafr El-Sheikh, Egypt in 2017 and 2018 rice growing seasons to explore the performance of Sakha 107 rice cultivar as affected by Mycorrhizal under different irrigation intervals. The soil was clayey in texture with $\mathrm{pH} 8.10$, organic matter $(\mathrm{OM})$ $1.54 \%$, total nitrogen $479 \mathrm{mg} \mathrm{kg}^{-1}$, available $\mathrm{P}$ $11 \mathrm{mg} \mathrm{kg}^{-1}$, available $\mathrm{K} 365 \mathrm{mg} \mathrm{kg}^{-1}$, available Zn $0.75 \mathrm{mg} \mathrm{kg}^{-1}$, available Fe $5.35 \mathrm{mg} \mathrm{kg}^{-1}$ and available $\mathrm{Mn} 2.85 \mathrm{mg} \mathrm{kg}$. Afield experiment was carried out as split-plot design, with three replications. Irrigation(as the main plots) was imposed at four treatments; namely, continuous flooding (I1), irrigation every 6 (I2), 9 (I3) and 12 days (I4). Arbuscular Mycorrhizal fungi (Glomus, Gigaspora and Acaulospora species) as biofertilizer was inoculated at two levels; control or without inoculation (M1) and inoculation the seeds in nursery bed by $1.2 \mathrm{~kg} \mathrm{ha}^{-1}$ of mycorrhizal biofertilizer (M2) and occupied the sub plot. Mycorrhizal biofertilizer was obtained from Agric. Microbial. Dept., Soil and Water Institute, Agricultural Research Center, Giza. It is worthy to mention that the main plots were surrounded 
by deep ditches to control and prevent any lateral movement of irrigation. Either of irrigation every 6, 9 and 12 days was started at 15 days after transplanting, with water depth of $5 \pm 1 \mathrm{~cm}$ at the time of irrigation, throughout the growing season. The amount of water applied for land preparation of both nursery and permanent field was recorded as well as water applied under different irrigation treatments. Productivity of irrigation water (PIW) was determined according to Ali et al. (2007) as follows:

$$
\begin{gathered}
\text { PIW = rice grain yield }\left(\mathrm{kg} \mathrm{ha}^{-1}\right) / \text { total } \\
\text { water used }\left(\mathrm{m}^{3} \mathrm{ha}^{-1}\right) .
\end{gathered}
$$

Seeds of Sakha 107 rice cultivar (144 kg seeds $\mathrm{ha}^{-1}$ ) were soaked in water for $24 \mathrm{hr}$, and then, incubated for $48 \mathrm{hr}$ to hasten early germination. Pre-germinated seeds were divided into two equal parts, the first part inoculated with mycorrhizal (AM) and the other part untreated with mycorrhizal. Pre-germinated seeds were uniformly broadcasted in the nursery on $7^{\text {th }}$ and $11^{\text {th }}$ May of the two seasons, respectively. Rice seedlings were transplanted to the field 30 days after sowing in $20 \times 20 \mathrm{~cm}$ space between rows and hills, with 3 seedlings hill-1 . Basal application of phosphorus and potassium fertilizers was applied to all plots and worked well into the soil during land preparation at the rate of $36 \mathrm{~kg} \mathrm{P}_{2} \mathrm{O}_{5}$ and 60 $\mathrm{kg} \mathrm{K} \mathrm{K}_{2} \mathrm{O}$ per hectare using single super phosphate and potassium sulfate fertilizers, respectively. Nitrogen fertilizer was applied at the rate of 165 $\mathrm{kg} \mathrm{N} \mathrm{ha}^{-1}$ in the form of urea $(46.5 \% \mathrm{~N})$. Urea was added in two splits, two third of $\mathrm{N}$ was applied as basal application, and the other third was top dressed at 35 days after transplanting. All other agronomic practices were done as recommended by RRTC, (2012). Plant samples (five hills) were taken randomly from each plot five days before harvest to estimate the plant height $(\mathrm{cm})$, number of tillers hill ${ }^{-1}$ and number of panicles hill-1. Ten panicles were collected randomly to estimate the panicle length, panicle weight, number of branches panicle ${ }^{-1}$, number of filled and sterility percentage per panicle, and 1000-grain weight. The crop of central $5 \mathrm{~m}^{2}$ of each plot was harvested separately at full maturity, dried, threshed, then grain and straw yields were recorded and each of them was converted into $\mathrm{tha}^{-1}$. The grain yield was adjusted at $14 \%$ moisture content. Sample of grain was taken at harvest to estimate nitrogen and phosphorus content as outlined by Jackson (1967). Data were statistically analyzed according to the proceeding described by Gomez and Gomez (1984). The differences among treatments were compared using Duncan's Multiple Range Test (DMRT, 1955).

\section{Results and Discussion}

\section{Plant height and number of tillers}

Data showed that plant height and number of tiller hill ${ }^{-1}$ at harvest was significantly affected by irrigation intervals. They were decreased as intervals period increased up to 12 days, in both seasons (Table 1). The reduction in plant height could be attributed to reduction in cell turger that causes reduction in cell enlargement, which in turn decreases shoots enlargement. However, the reduction in number of tiller hill ${ }^{-1}$ could be attributed to death or less ability of tiller nodes to produce more tillers under water stress. A similar trend was found by El-Refaee et al., (2012).

Data in Table 1 also indicated that inoculation of AMF significantly increase plant height and number of tiller hill ${ }^{-1}$ compared to non inoculation treatment. Increasing plant height and number of tiller due to AMF application could be attributed to the improve nutritional and leaf water status which helped the plants to translocate mineral nutrients and to assimilate them that resulted in increase the symbiosis process involves fluxes of photosynthates to shoots of rice plant. A similar trend was found by Barea et al. (2005) who stated that microorganisms of soil such as AM fungi symbiotically associated with roots of plant and interacting with specific microbial communities can increase a series of activities to enhance plant growth.

Significant variation in number of tillers hill ${ }^{-1}$ of Sakha 107 rice cultivar was observed due to the interaction between AMF application and irrigation intervals (Table 2). The combination of inoculation of AMF with continuous flooding (I1) or with irrigation every 6 days (I2) produced the maximum values of number of tillers hill-1 ${ }^{-1}$ The minimum number of tillers hill-1 was recorded with non inoculation treatment (M1) when irrigated every 12 days (I4). 
TABLE 1. Plant height and number of tiller hill ${ }^{-1}$ of Sakha 107 rice cultivar as affected by inoculation of AMF application and irrigation intervals.

\begin{tabular}{lcccc}
\hline \multirow{2}{*}{ Treatment } & \multicolumn{2}{c}{ Plant height (cm) } & \multicolumn{2}{c}{${\text { No. of tiller } \text { hill }^{-1}}^{-}$} \\
\cline { 2 - 5 } & 2017 & 2018 & 2017 & 2018 \\
\hline Irrig. Interv. (I) & & & & \\
Continuous flooding & $96.85 \mathrm{a}$ & $97.27 \mathrm{a}$ & $24.65 \mathrm{a}$ & $24.99 \mathrm{a}$ \\
6-day & $96.00 \mathrm{a}$ & $96.54 \mathrm{a}$ & $24.20 \mathrm{~b}$ & $24.43 \mathrm{~b}$ \\
9-day & $93.57 \mathrm{~b}$ & $94.07 \mathrm{~b}$ & $23.03 \mathrm{c}$ & $23.61 \mathrm{c}$ \\
12-day & $91.58 \mathrm{c}$ & $92.42 \mathrm{c}$ & $21.13 \mathrm{~d}$ & $21.77 \mathrm{~d}$ \\
Inoc. AMF( M) & & & & \\
Without (M1) & $93.52 \mathrm{~b}$ & $94.09 \mathrm{~b}$ & $22.76 \mathrm{~b}$ & $23.12 \mathrm{~b}$ \\
With (M2) & $95.48 \mathrm{a}$ & $96.06 \mathrm{a}$ & $23.75 \mathrm{a}$ & $24.28 \mathrm{a}$ \\
I x M & $\mathrm{NS}$ & $\mathrm{NS}$ & $*$ & $*$ \\
\hline
\end{tabular}

Means not sharing the same letter significantly differ using DMRT.

$*=$ Significant at 0.05 level, $* *=$ Significant at 0.01 level and NS= Not significant.

TABLE 2. Number of tiller hill ${ }^{-1}$ of Sakha 107 rice cultivar as affected by interaction between inoculation of AMF application and irrigation intervals.

\begin{tabular}{|c|c|c|c|c|c|c|c|c|}
\hline \multicolumn{9}{|c|}{ Number of tillers hill ${ }^{-1}$} \\
\hline & \multicolumn{4}{|c|}{2017} & \multicolumn{4}{|c|}{2018} \\
\hline & I1 & $\mathbf{I 2}$ & I3 & I4 & I1 & I2 & I3 & I4 \\
\hline M1 & $2431 \mathrm{~h}$ & 2357 r & $2260 d$ & $2057 f$ & $2438 \mathrm{~b}$ & 2300 & $2313 d$ & 21078 \\
\hline M2 & $25.00 \mathrm{a}$ & $24.82 \mathrm{a}$ & $23.47 \mathrm{c}$ & $21.70 \mathrm{e}$ & $25.60 \mathrm{a}$ & $24.97 \mathrm{ab}$ & $24.08 \mathrm{c}$ & $22.47 \mathrm{e}$ \\
\hline
\end{tabular}

$\mathrm{I} 1=$ Continuous flooding, $\mathrm{I} 2=$ irrigation every 6 -day, I3 = irrigation every 9-day and I4= irrigation every 12-day

$\mathrm{M} 1=$ without inoculation and M2= inoculation mycorrhizal

Means not sharing the same letter significantly differ using DMRT.

\section{Grain yield attributes}

Data in Tables 3 and 4 indicated that grain yield attributes were significantly affected by irrigation intervals. They were reduced as off period increased up to 12-days, in both seasons. The highest values of all traits were obtained with continuous flooding followed by irrigation every 6-days except sterility (\%), which gave opposite trend. Such increment in grain yield attributes under non stress condition could be due to that reality a vailable water enhanced the biological and physiological process which increase the production and translocation of the dry matter content from source to sink which resulting in more panicles, grain filling and weight. These results are in harmony with those stated by El-
Refaee et al., (2005) and Zubaer et al. (2007).

Data also showed that in both seasons no significant differences between inoculations of AMF treatments on panicle length and number of branches panicle ${ }^{-1}$. While, there were significant difference between inoculations of AMF treatments on panicle weight, number of panicles hill $^{-1}$, number of filled grain panicle ${ }^{-1}$, sterility (\%) and 1000-grain weight (Tables 3 and 4). The highest values of all traits were obtained with inoculated of AMF (M2) except sterility \%, which gave the highest values with non inoculation treatment (M1) (Tables 3 and 4). 
TABLE 3. Panicle weight, panicle length, number of panicles hill ${ }^{-1}$ and number of branches panicle ${ }^{-1}$ of Sakha 107 rice cultivar as affected by inoculation of AMF application and irrigation intervals.

\begin{tabular}{|c|c|c|c|c|c|c|c|c|}
\hline \multirow{2}{*}{ Treatment } & \multicolumn{2}{|c|}{ Panicle weight (g) } & \multicolumn{2}{|c|}{$\begin{array}{l}\text { Panicle length } \\
\text { (cm) }\end{array}$} & \multicolumn{2}{|c|}{$\begin{array}{c}\text { No. of panicles } \\
\text { hill }^{-1}\end{array}$} & \multicolumn{2}{|c|}{$\begin{array}{c}\text { NO. of branches } \\
\text { panicle }^{-1}\end{array}$} \\
\hline & 2017 & 2018 & 2017 & 2018 & 2017 & 2018 & 2017 & 2018 \\
\hline \multicolumn{9}{|l|}{ Irrig. Interv. (I) } \\
\hline Continuous flooding & $2.94 \mathrm{a}$ & $2.89 \mathrm{a}$ & $17.78 \mathrm{a}$ & $18.00 \mathrm{a}$ & $22.90 \mathrm{a}$ & $23.44 \mathrm{a}$ & $9.03 \mathrm{a}$ & $9.37 \mathrm{a}$ \\
\hline 6-day & $2.81 \mathrm{a}$ & $2.82 \mathrm{a}$ & $17.42 \mathrm{ab}$ & $17.84 \mathrm{a}$ & $22.45 b$ & $22.88 b$ & $8.62 \mathrm{ab}$ & $8.97 \mathrm{~b}$ \\
\hline 9-day & $2.65 b$ & $2.65 b$ & $16.97 b$ & $17.13 b$ & $20.91 \mathrm{c}$ & $21.43 \mathrm{c}$ & $8.38 b$ & $8.68 \mathrm{c}$ \\
\hline 12-day & $2.52 \mathrm{c}$ & $2.51 \mathrm{c}$ & $16.83 b$ & $16.96 \mathrm{~b}$ & $19.01 \mathrm{~d}$ & $19.59 \mathrm{~d}$ & $8.13 b$ & $8.47 \mathrm{~d}$ \\
\hline \multicolumn{9}{|l|}{ Inoc. $\operatorname{AMF}(M)$} \\
\hline Without (M1) & $2.56 \mathrm{~b}$ & $2.61 b$ & $16.97 \mathrm{a}$ & $17.22 \mathrm{a}$ & $20.51 b$ & $20.87 b$ & $8.48 \mathrm{a}$ & $8.74 \mathrm{a}$ \\
\hline With (M2) & $2.91 \mathrm{a}$ & $2.82 \mathrm{a}$ & $17.52 \mathrm{a}$ & $17.75 \mathrm{a}$ & $22.51 \mathrm{a}$ & $22.80 \mathrm{a}$ & $8.61 \mathrm{a}$ & $9.00 \mathrm{a}$ \\
\hline I $x M$ & $*$ & $*$ & NS & NS & $* *$ & $* *$ & NS & NS \\
\hline
\end{tabular}

Means not sharing the same letter significantly differ using DMRT.

$*=$ Significant at 0.05 level, $* *=$ Significant at 0.01 level and NS= Not significant.

TABLE 4. Number of filled grains panicle ${ }^{-1}$, sterility $\%$, and 1000-grain weight of Sakha 107 rice cultivar as affected by inoculation of AMF application and irrigation intervals.

\begin{tabular}{|c|c|c|c|c|c|c|}
\hline \multirow{2}{*}{ Treatment } & \multicolumn{2}{|c|}{ No. of filled grain panicle ${ }^{-1}$} & \multicolumn{2}{|c|}{ Sterility \% } & \multicolumn{2}{|c|}{1000 -grain weight (g) } \\
\hline & 2017 & 2018 & 2017 & 2018 & 2017 & 2018 \\
\hline \multicolumn{7}{|l|}{ Irrig. Interv. (I) } \\
\hline Continuous flooding & $102.35 \mathrm{a}$ & $105.60 \mathrm{a}$ & $5.03 \mathrm{~d}$ & $5.53 \mathrm{~d}$ & $27.71 \mathrm{a}$ & $28.00 \mathrm{a}$ \\
\hline 6-day & $99.63 b$ & $102.47 \mathrm{~b}$ & $6.99 \mathrm{c}$ & $6.95 c$ & $27.50 \mathrm{a}$ & $27.75 \mathrm{ab}$ \\
\hline 9-day & $95.28 \mathrm{c}$ & $97.28 \mathrm{c}$ & $8.58 \mathrm{~b}$ & $8.43 b$ & $26.92 b$ & $27.53 b$ \\
\hline 12-day & $88.17 d$ & $90.08 \mathrm{~d}$ & $10.09 \mathrm{a}$ & $10.54 \mathrm{a}$ & $26.85 b$ & $27.03 \mathrm{c}$ \\
\hline \multicolumn{7}{|l|}{ Inoc. $\operatorname{AMF}(\mathbf{M})$} \\
\hline Without (M1) & $94.48 b$ & $97.06 \mathrm{~b}$ & $8.33 \mathrm{a}$ & $8.70 \mathrm{a}$ & $27.03 b$ & $27.24 b$ \\
\hline With (M2) & $98.24 \mathrm{a}$ & $100.66 \mathrm{a}$ & $7.01 \mathrm{~b}$ & $7.02 \mathrm{~b}$ & $27.45 \mathrm{a}$ & $27.91 \mathrm{a}$ \\
\hline IxM & $* *$ & $* *$ & $* *$ & $* *$ & NS & NS \\
\hline
\end{tabular}

Means not sharing the same letter significantly differ using DMRT.

$*=$ Significant at 0.05 level, $* *=$ Significant at 0.01 level and NS $=$ Not significant.

Significant variation in most of yield attributes of Sakha 107 rice cultivar was observed due to the interaction between AMF application and irrigation intervals (Table 5). The combination of inoculation of AMF (M2) with continuous flooding followed by AMF application (M2) combined with irrigation every 6-days produced the maximum values of panicle weight, number of panicles hill-1 , and number of filled grain panicle ${ }^{-1}$. While the minimum values of panicle weight, number of panicles hill-1, and number of filled grain panicle ${ }^{-1}$ were obtained with non inoculation treatment (M1) which irrigated every 12-day. On the other hand, the highest sterility (\%) was recorded with non inoculation treatment (M1) which irrigated every 12-day, while the lowest sterility (\%) was recorded with inoculation of AMF (M2) combined with continuous flooding. It is worth to notice that under all irrigation treatments inoculation of AMF (M2) caused an increase in most traits of yield attributes as compared with non inoculation treatment (M1). These results are in conformity with those obtained by Panneerselvam et al. (2017) who mentioned that AMF is capable of applying as the technique for sustainable rice productivity. AMF plays an important role in nutrients management by supplying rice by essential nutrients. Moreover, AMF work both in submerged and non-submerged rice with improvement in productivity. 
Grain and straw yields

Grain and straw yields of the Sakha 107 rice cultivar significantly affected by Mycorrhizal inoculation, different irrigation treatments and their interaction (Table 6). Data revealed that prolonging irrigation intervals caused a reduction in the yield. Continuous flooding recorded the highest grain and straw yield followed by irrigation every 6-day without any significant differences between them. The reduction in grain yield as affected by prolonging the irrigation intervals may be attributed to the reduction in dry matter production, panicle weight, number of panicles hill' ${ }^{-1}$, number of filled grain panicle ${ }^{-1}$ and 1000-grain weight. However, the reduction in straw yield as affected by prolonging the irrigation intervals may be due to the decrease in dry matter production, plant height and number of tiller hill $^{-1}$. A similar trend was found by Bozorgi et al. (2011) and El-Refaee et al. (2012) who found that flooding irrigation gave the highest grain yield. Also, the irrigation every 6-day was statistically placed in the same level with flooded method. This might be due to better growth characters (dry matter, chlorophyll content and plant height) associated with higher mobility and absorption of mineral nutrients in soil solution, which enhanced the uptake of nutrients and contributed to favourable growth attributes consequently resulted in production higher yield.

TABLE 5. Panicle weight, number of panicles hill- ${ }^{-1}$, number of filled grains panicle ${ }^{-1}$ and Sterility (\%) of Sakha 107 rice cultivar as affected by interaction between inoculation of AMF application and irrigation intervals.

\begin{tabular}{|c|c|c|c|c|c|c|c|c|}
\hline \multicolumn{9}{|c|}{ Panicle weight (g) } \\
\hline \multicolumn{9}{|c|}{2018} \\
\hline & I1 & I 2 & I3 & I4 & I1 & $\mathbf{I} 2$ & I3 & I4 \\
\hline $\mathrm{M} 1$ & $283 \mathrm{~b}$ & $261 \mathrm{c}$ & $250 \mathrm{c}$ & $231 \mathrm{~d}$ & $283 \mathrm{~b}$ & 260 & 55 & \\
\hline \multirow{2}{*}{ M2 } & $305 a$ & $302 a$ & $281 \mathrm{~b}$ & $274 \mathrm{~b}$ & $2.95 \mathrm{a}$ & $296 a$ & $274 \mathrm{~b}$ & $264 \mathrm{~b}$ \\
\hline & \multicolumn{8}{|c|}{ Number of panicles hill-1 } \\
\hline M1 & $22.31 b$ & $21.57 \mathrm{c}$ & $20.10 \mathrm{~d}$ & $18.07 \mathrm{f}$ & $22.63 b$ & $22.15 b$ & $20.38 \mathrm{~d}$ & $18.32 \mathrm{e}$ \\
\hline \multirow[t]{2}{*}{ M2 } & $23.50 \mathrm{a}$ & $23.32 \mathrm{a}$ & $21.71 \mathrm{c}$ & $19.95 \mathrm{e}$ & $24.25 \mathrm{a}$ & $23.62 \mathrm{ab}$ & $22.48 b$ & $20.87 \mathrm{c}$ \\
\hline & \multicolumn{8}{|c|}{ Number of filled grains panicle ${ }^{-1}$} \\
\hline M1 & $101.17 b$ & $97.43 \mathrm{c}$ & $93.47 \mathrm{~d}$ & $85.83 \mathrm{f}$ & $104.50 \mathrm{~b}$ & $100.93 c$ & $94.80 \mathrm{~d}$ & $88.00 \mathrm{f}$ \\
\hline \multirow[t]{2}{*}{ M2 } & $103.53 \mathrm{a}$ & $101.83 b$ & $97.10 \mathrm{c}$ & $90.50 \mathrm{e}$ & $106.70 \mathrm{a}$ & $104.00 \mathrm{~b}$ & $99.77 \mathrm{c}$ & $92.17 \mathrm{e}$ \\
\hline & \multicolumn{8}{|c|}{ Sterility (\%) } \\
\hline M1 & $5.11 \mathrm{e}$ & $7.45 \mathrm{~cd}$ & $9.16 b$ & $11.59 \mathrm{a}$ & $5.82 \mathrm{e}$ & $7.51 \mathrm{c}$ & $9.48 b$ & $12.01 \mathrm{a}$ \\
\hline M2 & $4.94 \mathrm{e}$ & $6.52 \mathrm{~d}$ & $8.00 \mathrm{c}$ & $8.59 \mathrm{c}$ & $5.23 \mathrm{f}$ & $6.40 \mathrm{c}$ & $7.39 \mathrm{c}$ & $9.07 \mathrm{~b}$ \\
\hline
\end{tabular}

$\mathrm{I} 1=$ Continuous flooding, $\mathrm{I} 2=$ irrigation every 6 -day, $\mathrm{I} 3=$ irrigation every 9-day and $\mathrm{I} 4=$ irrigation every 12 -day $\mathrm{M} 1=$ without inoculation and M2= inoculation mycorrhizal

Means not sharing the same letter significantly differ using DMRT.

TABLE 6. Grain and straw yields of Sakha 107 rice cultivar as affected by inoculation of AMF application and irrigation intervals.

\begin{tabular}{lcccc}
\hline \multirow{2}{*}{ Treatment } & \multicolumn{2}{c}{ Grain yield t ha $^{-1}$} & \multicolumn{2}{c}{ Straw yield t ha $^{-1}$} \\
\cline { 2 - 4 } & $\mathbf{2 0 1 7}$ & $\mathbf{2 0 1 8}$ & $\mathbf{2 0 1 7}$ & $\mathbf{2 0 1 8}$ \\
\hline Irrig. Interv. (I) & & & & $11.97 \mathrm{a}$ \\
Continuous flooding & $10.33 \mathrm{a}$ & $10.50 \mathrm{a}$ & $11.41 \mathrm{a}$ & $11.59 \mathrm{a}$ \\
6-day & $9.94 \mathrm{a}$ & $10.19 \mathrm{a}$ & $10.40 \mathrm{~b}$ & $10.62 \mathrm{~b}$ \\
9-day & $8.97 \mathrm{~b}$ & $9.15 \mathrm{~b}$ & $9.74 \mathrm{c}$ & $9.83 \mathrm{c}$ \\
12-day & $8.25 \mathrm{c}$ & $8.47 \mathrm{c}$ & & $10.56 \mathrm{~b}$ \\
Inoc. AMF(M) & & & & $11.55 \mathrm{a}$ \\
Without (M1) & $8.95 \mathrm{~b}$ & $9.12 \mathrm{~b}$ & $10.43 \mathrm{~b}$ & $* 3$ \\
With (M2) & $9.79 \mathrm{a}$ & $10.04 \mathrm{a}$ & $11.32 \mathrm{a}$ & $* *$ \\
IxM & $* *$ & $* *$ & & $*$ \\
\hline
\end{tabular}

Means not sharing the same letter significantly differ using DMRT.

$*=$ Significant at 0.05 level, $* *=$ Significant at 0.01 level and NS= Not significant.

Env. Biodiv. Soil Security Vol. 3 (2019) 
As for Arbuscular Mycorrhizal treatments, data showed that inoculation seeds in nursery bed with AMF (M2) significantly increase grain and straw yields compared to non inoculation treatment (M1) (Table 6).

Nursery inoculation of Mycorrhizal increased the grain yield of rice by $14-21 \%$. It might be due to the role of AMF for enhancing accelerates the water and nutrients transfer from soil to shoots resulting in increase rice grain yield in aerobic and anaerobic rice cultivation system and improves the harvest index (Solaiman and Hirata 1997). A similar trend was found by Garcia de Salamone et al., (2010) who reported that the positive influence of inoculation with Mycorrhizal on dry matter accumulation and grain productivity of rice plants cultivated under field condition.

Data in Table 7 clarified that there was a significant difference among the interaction treatments. The combination of each inoculation of AMF treatments with any irrigation treatments caused an increase in grain and straw yields as compared with non inoculation of AMF. The greatest grain and straw yields were produced when inoculation of AMF treatment was combined with either continuous flooding or irrigation every 6-day. It is worthy to note that with prolonging irrigation period (water Stress increased), grain yield affected positively to AMF inoculation. Under the same irrigation treatment, AMF inoculation increased grain yield by about $4.32,7.90,13.05$ and $15.47 \%$ relative to non inoculation plants for I1, I2, I3 and I4 treatments, respectively. Panneerselvam et al. (2017) reported that AMF performs an important role in reserving plant against osmotic stress by shifting water motion in the host plants. Hyphae of AMF is very slim with a thickness of $2-5 \mathrm{~nm}$ thus, it be able to insert the soil pore which the root hairs cannot penetrate $(10-20 \mathrm{~nm}$ diameter) so, Hyphae capable take up moisture inaccessible to plants. The rate of water moving by further radial hyphae to root capable to adjust plant water relations. Ruiz- Sanchez et al. (2017) reported that inoculation by AM fungus increased protective compounds such as ascorbate and proline which cope the harmful impacts of drought stress.

\section{Nutrients uptake kg ha-1 by grain yield}

Nutrients ( $\mathrm{N}$ and $\mathrm{P}$ ) uptake by grain yield of Sakha 107 rice cultivar was significantly affected by different irrigation treatments, mycorrhizal inoculation and their interactions (Table 8). Data indicated that prolonging the irrigation intervals caused a reduction in the uptake of $\mathrm{N}$ and $\mathrm{P}$ by grain. Continuous flooding recorded the highest $\mathrm{N}$ and $\mathrm{P}$ uptake followed by irrigation every 6-day. This might be due to the fact that under adequate soil moisture there is more solubilization of nutrients and thereby increasing more availability to plants and hence increased uptake. This result was in conformity with the findings of Sandhu and Mahal (2014).

Data also showed that inoculation of AMF significantly increase $\mathrm{N}$ and $\mathrm{P}$ uptake by grain yield compared to non inoculation treatment. AMF-plant symbiotic association is very much beneficial for the growth and improvement of colonized host plants via facilitating an extensive surface area for $\mathrm{P}$ sorption via translocation by mycelium or hyphae to the roots of host plant.

TABLE 7. Grain yield $t \mathrm{th}^{-1}$ and Straw yield $\mathrm{tha}^{-1}$ of Sakha 107 rice cultivar as affected by interaction between inoculation of AMF application and irrigation intervals.

\begin{tabular}{|c|c|c|c|c|c|c|c|c|}
\hline \multirow{3}{*}{$\begin{array}{l}\text { Trrigation } \\
\text { Ino. of AMF }\end{array}$} & \multicolumn{8}{|c|}{ Grain yield $t h^{-1}$} \\
\hline & \multicolumn{4}{|c|}{2017} & \multicolumn{4}{|c|}{2018} \\
\hline & I1 & I2 & I3 & I4 & I1 & I 2 & I3 & I4 \\
\hline M1 & $10.12 b$ & $9.57 \mathrm{c}$ & $8.44 \mathrm{e}$ & $7.67 f$ & $10.26 \mathrm{~b}$ & $9.79 \mathrm{c}$ & $8.57 \mathrm{e}$ & $7.84 f$ \\
\hline M2 & $10.53 a$ & $10.30 \mathrm{a}$ & $9.49 \mathrm{c}$ & $8.82 \mathrm{~d}$ & $10.73 \mathrm{a}$ & $10.59 \mathrm{a}$ & $9.74 \mathrm{c}$ & $9.09 \mathrm{~d}$ \\
\hline \multirow[t]{2}{*}{ Change \% } & 4.05 & 7.63 & 12.44 & 14.99 & 4.58 & 8.17 & 13.65 & 15.94 \\
\hline & \multicolumn{8}{|c|}{ Straw yield $\mathbf{t} \mathbf{h a}^{-1}$} \\
\hline M1 & $11.68 \mathrm{~b}$ & $11.07 \mathrm{c}$ & $9.90 \mathrm{~d}$ & $9.09 \mathrm{e}$ & $11.85 b$ & $11.17 \mathrm{c}$ & $10.04 \mathrm{e}$ & $9.16 \mathrm{f}$ \\
\hline M2 & $12.27 \mathrm{a}$ & $11.75 b$ & $10.89 \mathrm{c}$ & $10.38 \mathrm{c}$ & $12.47 \mathrm{a}$ & $12.00 \mathrm{~b}$ & $11.21 \mathrm{c}$ & $10.51 \mathrm{~d}$ \\
\hline
\end{tabular}

$\mathrm{I} 1=$ Continuous flooding, I2= irrigation every 6-day, I3 = irrigation every 9-day and I4= irrigation every 12-day

$\mathrm{M} 1=$ without inoculation and M2= inoculation mycorrhizal

Means not sharing the same letter significantly differ using DMRT. 
TABLE 8. $\mathrm{N}$ and $\mathrm{P}$ uptake $\left(\mathrm{kg} \mathrm{ha}^{-1}\right)$ by grain yield as affected by inoculation of AMF application and irrigation intervals.

\begin{tabular}{lcccc}
\hline \multirow{2}{*}{ Treatment } & \multicolumn{2}{c}{$\mathbf{N}$ uptake $\left(\mathbf{k g ~ h a}^{-1}\right)$ by grain yield } & P uptake $\left(\mathbf{k g ~ h}^{-1}\right)$ by grain yield \\
\cline { 2 - 5 } & $\mathbf{2 0 1 7}$ & $\mathbf{2 0 1 8}$ & $\mathbf{2 0 1 7}$ & $\mathbf{2 0 1 8}$ \\
\hline Irrig. Interv. (I) & & & & \\
Continuous flooding & $104.27 \mathrm{a}$ & $105.30 \mathrm{a}$ & $21.95 \mathrm{a}$ & $22.39 \mathrm{a}$ \\
6-day & $99.66 \mathrm{~b}$ & $101.39 \mathrm{~b}$ & $18.21 \mathrm{~b}$ & $18.21 \mathrm{~b}$ \\
9-day & $88.09 \mathrm{c}$ & $89.33 \mathrm{c}$ & $15.74 \mathrm{c}$ & $16.23 \mathrm{c}$ \\
12-day & $79.84 \mathrm{~d}$ & $83.58 \mathrm{~d}$ & $14.42 \mathrm{~d}$ & $14.94 \mathrm{~d}$ \\
Inoc. AMF( M) & & & & \\
Without (M1) & $89 . .67 \mathrm{~b}$ & $91.55 \mathrm{~b}$ & $16.32 \mathrm{~b}$ & $17.02 \mathrm{~b}$ \\
With (M2) & $96.26 \mathrm{a}$ & $98.25 \mathrm{a}$ & $18.85 \mathrm{a}$ & $18.87 \mathrm{a}$ \\
MxI & $* *$ & $* *$ & $*$ & $*$ \\
\hline
\end{tabular}

Means not sharing the same letter significantly differ using DMRT.

$*$ = Significant at 0.05 level, $* *=$ Significant at 0.01 level and NS= Not significant.

Panneerselvam et al. (2013) and Sahoo et al. (2017) documented that AMF increased nutrients availability to plants, in especially mineral orthophosphate, via establishment far-reaching extra radical mycelia (hyphae) that work as functional extensions of the plant root system. AM fungal are effective in increasing phosphorus uptake through two mechanisms. First, it produces phosphatase enzymes which cleave ester bonds that tie $\mathrm{P}$ to $\mathrm{C}$ in organic matter, thereby releasing phosphate that can be absorbed by the fungi and transmitted to the plant. Second, it produces low molecular weight organic acids, such as oxalates, which increase the soil $\mathrm{P}$ availability by enhancing weathering rates of $\mathrm{P}$ contained in clay minerals (Bardgett, 2005). Also, AMF promotes $\mathrm{P}$ absorption by rising its solubility in soil due to $\mathrm{pH}$ changes or by exudation of $\mathrm{P}$ mobilizing compounds such as organic acids and phosphatases (Tawaraya et al., 2006).

Data in Table 9 showed that there were significant variations among the interaction treatments. The combination of inoculation of AMF treatments (M2) with any irrigation treatments resulted in marked increases in $\mathrm{N}$ and $\mathrm{P}$ uptakes by grain as compared with non inoculation of AMF. The maximum values of $\mathrm{N}$ and $\mathrm{P}$ uptakes by grain were obtained when inoculation of AMF treatment was applied with continuous flooding. The minimum values of $\mathrm{N}$ and $\mathrm{P}$ uptakes by grain were obtained when non inoculation treatment was applied under irrigation every 12-day.

Env. Biodiv. Soil Security Vol. 3 (2019)

\section{Water relations}

Data in Table 10 indicate that the amount of water consumed along the season including water used for land preparation for both nursery and permanent field, raising nursery for 30 days and through 15 days after transplanting (DAT) before irrigation treatments application as well as the amount of water needed to replenish were 4645.60 and 4595.00 in 2017 and 2018 seasons, respectively. Data in the same table showed that the highest amount of irrigation water used through treatments which started 15 DAT was recorded by I1 treatment, while the least amount was obtained from I4 treatment in both seasons. This difference in irrigation water was mainly due to number of irrigation implied under each irrigation treatment. It's easily to note that the same trend was found with total irrigation water which consumed through treatments. A similar trend was found by El-Refaee et al. (2012).

Data in Table 10 showed that the averages of grain yield redaction were found to be $3.48,14.96$ and $24.59 \%$ with corresponding values of water saved of $9.21,15.32$ and 24.76 when the irrigation interval period was prolonged up to 6,9 and 12day, respectively. A similar trend was found by ElRefaee et al., (2012).

Concerning productivity of irrigation water (PIW), data in Table 11 revealed that application of inoculation AMF gave the highest PIW compared to non inoculation treatment in both seasons. Colonization commonly adjusted root properties, e.g. the specific root length and root 
TABLE 9. $\mathrm{N}$ and $\mathrm{P}$ uptake $\left(\mathrm{kg} \mathrm{ha}^{-1}\right)$ by grain yield as affected by interaction between inoculation of AMF application and irrigation intervals.

\begin{tabular}{|c|c|c|c|c|c|c|c|c|}
\hline \multicolumn{9}{|c|}{$\mathrm{N}$ uptake $\left(\mathrm{kg} \mathrm{ha}^{-1}\right)$ by grain yield } \\
\hline & \multicolumn{4}{|c|}{2017} & \multicolumn{4}{|c|}{2018} \\
\hline $\begin{array}{l}\text { Irrigation } \\
\text { Ino. of AMF }\end{array}$ & I1 & I2 & I3 & I4 & I1 & $\mathbf{I} 2$ & I3 & I4 \\
\hline M1 & $102.80 \mathrm{a}$ & $96.32 b$ & $83.51 \mathrm{~d}$ & $76.03 \mathrm{e}$ & $104.03 \mathrm{a}$ & $99.08 b$ & $83.96 \mathrm{e}$ & $79.12 \mathrm{f}$ \\
\hline \multirow[t]{2}{*}{ M2 } & $105.73 a$ & $102.99 a$ & $92.66 \mathrm{c}$ & $83.66 \mathrm{~d}$ & $106.56 \mathrm{a}$ & $103.70 \mathrm{a}$ & $94.70 \mathrm{c}$ & $88.04 d$ \\
\hline & \multicolumn{8}{|c|}{ P uptake $\left(\mathrm{kg} \mathrm{ha}^{-1}\right)$ by grain yield } \\
\hline M1 & $20.57 b$ & $17.22 \mathrm{~d}$ & $14.44 \mathrm{e}$ & $13.05 \mathrm{f}$ & $21.31 \mathrm{~b}$ & $17.39 \mathrm{~d}$ & $15.23 \mathrm{e}$ & $14.15 f$ \\
\hline M2 & $23.32 \mathrm{a}$ & $19.21 \mathrm{c}$ & $17.05 \mathrm{~d}$ & $15.79 \mathrm{e}$ & $23.47 \mathrm{a}$ & $19.04 \mathrm{c}$ & $17.24 d$ & $15.73 \mathrm{e}$ \\
\hline
\end{tabular}

$\mathrm{I} 1=$ Continuous flooding, $\mathrm{I} 2=$ irrigation every 6-day, I3 = irrigation every 9-day and I4= irrigation every 12-day

$\mathrm{M} 1=$ without inoculation and M2= inoculation mycorrhizal

Means not sharing the same letter significantly differ using DMRT.

TABLE 10. Water consumed $\left(\mathrm{m}^{3} \mathrm{ha}^{-1}\right)$ in rice field before and after application irrigation treatments.

\begin{tabular}{|c|c|c|c|c|c|}
\hline Period of irrigation & 2017 & & 2018 & \multicolumn{2}{|c|}{ Average } \\
\hline \multicolumn{6}{|l|}{ A-BEFORE IRRIGATION TREATMENTS } \\
\hline Land preparation of the nursery & \multicolumn{2}{|l|}{203.7} & 196.1 & \multicolumn{2}{|c|}{199.9} \\
\hline Raising seedling (30days) & \multicolumn{2}{|l|}{476.2} & 459.2 & \multicolumn{2}{|c|}{467.7} \\
\hline Preparation of permanent field & \multicolumn{2}{|l|}{2184.5} & 2176.1 & \multicolumn{2}{|c|}{2180.3} \\
\hline 15 days before irrigation treatments & \multicolumn{2}{|l|}{1781.2} & 1763.6 & \multicolumn{2}{|c|}{1772.4} \\
\hline Total & \multicolumn{2}{|l|}{4645.6} & 4595.0 & \multicolumn{2}{|c|}{4620.3} \\
\hline \multirow{2}{*}{$\underline{B \text {-After irrigation treatments }}$} & \multirow{2}{*}{2017} & \multirow{2}{*}{2018} & \multicolumn{2}{|c|}{ Total water used $\left(\mathrm{m}^{3} \mathrm{ha}^{-1}\right)$} & \multirow{2}{*}{ Average } \\
\hline & & & 2017 & 2018 & \\
\hline Continuous flooding & 9532.7 & 9498.4 & 14178.3 & 14093.4 & 14135.9 \\
\hline 6-day & 8231.9 & 8196.8 & 12877.5 & 12791.8 & 12834.6 \\
\hline 9-day & 7376.5 & 7322.7 & 12022.1 & 11917.7 & 11969.9 \\
\hline 12-day & 5928.8 & 6102.0 & 10574.4 & 10697.0 & 10635.7 \\
\hline
\end{tabular}

TABLE 11. Total amount of water consumed, water save $\%$ and yield reduction as affected by irrigation treatments.

\begin{tabular}{cccccccccc}
\hline \multirow{2}{*}{$\begin{array}{c}\text { Irrigation } \\
\text { Treatment }\end{array}$} & \multicolumn{2}{c}{ Total water used $\left(\mathbf{m}^{\mathbf{3}} \mathbf{f e d}^{-\mathbf{1}}\right)$} & \multicolumn{3}{c}{ Water saved (\%) } & \multicolumn{2}{c}{ Grain yield reduction (\%) } \\
\cline { 2 - 9 } & $\mathbf{2 0 1 7}$ & $\mathbf{2 0 1 8}$ & Average & $\mathbf{2 0 1 7}$ & $\mathbf{2 0 1 8}$ & Average & $\mathbf{2 0 1 7}$ & $\mathbf{2 0 1 8}$ & Average \\
\cline { 2 - 9 } Con. flooding & 14178.3 & 14093.4 & 14135.9 & - & - & - & - & - & - \\
6-day & 12877.5 & 12791.8 & 12734.6 & 9.17 & 9.24 & 9.21 & 3.04 & 3.92 & 3.48 \\
9-day & 12022.1 & 11917.7 & 11969.9 & 15.21 & 15.44 & 15.32 & 14.75 & 15.16 & 14.96 \\
12-day & 10574.4 & 10697.0 & 10635.7 & 25.42 & 24.10 & 24.76 & 23.97 & 25.21 & 24.59 \\
\hline
\end{tabular}

construction, thus it could raise the absorption of diffusion limited nutrients comparative to nonAM plants, AM frequently enhances the canopy of host plant under drought stress (Khalvati et al., 2010 and Ruiz-Sánchez et al., 2010). The potential mechanisms suggested to explain the induction of drought stress tolerance by AM symbiosis involve developed regulation of the plant water relationships, a greater osmotic modification, an improved antioxidant defense and producing the protective molecules (Ruiz-Sánchez et al., 2010). Also, the exterior soil mycelium can steady the soil aggregates, and then enhanced the moisture retention and develop the water uptake (Rillig and Mummey 2006).

Env. Biodiv. Soil Security Vol. 3 (2019) 
TABLE 12. Productivity of irrigation water (PIW) of Sakha 107 rice cultivar as affected by inoculation of AMF application and irrigation intervals.

\begin{tabular}{lcccccc}
\hline \multirow{2}{*}{ Irrigation Treatment } & \multicolumn{3}{c}{$\mathbf{2 0 1 7}$} & \multicolumn{3}{c}{$\mathbf{2 0 1 8}$} \\
\cline { 2 - 7 } & M1 & M2 & Average & M1 & M2 & Average \\
\hline \multirow{2}{*}{ Con. flooding } & 0.714 & 0.747 & $\mathbf{0 . 7 3 0}$ & 0.728 & 0.761 & $\mathbf{0 . 7 4 5}$ \\
6-day & 0.743 & 0.805 & $\mathbf{0 . 7 7 4}$ & 0.765 & 0.828 & $\mathbf{0 . 7 9 7}$ \\
9-day & 0.702 & 0.796 & $\mathbf{0 . 7 4 9}$ & 0.719 & 0.817 & $\mathbf{0 . 7 8 8}$ \\
12-day & 0.725 & 0.825 & $\mathbf{0 . 7 7 5}$ & 0.733 & 0.850 & $\mathbf{0 . 7 9 1}$ \\
\multicolumn{1}{c}{ Average } & $\mathbf{0 . 7 2 1}$ & $\mathbf{0 . 7 9 3}$ & $\mathbf{0 . 7 5 7}$ & $\mathbf{0 . 7 3 6}$ & $\mathbf{0 . 8 1 4}$ & $\mathbf{0 . 7 7 5}$ \\
\hline
\end{tabular}

M1= without inoculation and M2= inoculation mycorrhizal

Data in Table 12 also, indicted that generally, irrigation every 6-day and irrigation every 12-day gave the highest values of PIW. These results are in harmony with those obtained by El-Refaee et al., (2012) and Omar et al., (2015) who reported that irrigation at 12-day was considered the best PIW followed by 6-day treatment this might by caused by the extremely high grain yield and low water inputs in these treatments compared with continuous flooding treatment. Data in the same table revealed that inoculation AMF treatment with any of irrigation treatments resulted in increase the productivity of irrigation water. Inoculation AMF was more effective toward stress condition. However, the combination of inoculation AMF treatment with irrigation every 6 and12-day gave the maximum values of PIW. Azcón and Barea (2010) stated that growth of rice plant significantly responded for AMF inoculation. Consequently, the results show evidence of the importance of mycorrhization of rice plant under both flooded and water deficit stress conditions, however it was more effective under stress condition.

\section{Conclusion}

Continuous flooding gave the highest grain and straw yield followed by irrigation every 6-day. Inoculation seeds with Arbuscular Mycorrhizal Fungi (AMF) in nursery rice bed increased the yield and its attributes, $\mathrm{N}$ and $\mathrm{P}$ uptake by grain yield and productivity of irrigation water (PIW) under both well-watered and drought stress conditions, however inoculation AMF was more efficient under water stress condition.

\section{References}

Ali, M. H.; M. R. Hoqu; A. A. Hassan and A. Kair (2007) Effect of deficit irrigation on yield, water productivity and economic returns of wheat.

Env. Biodiv. Soil Security Vol. 3 (2019)
Agricultural Management, 92(30):151-161

Azcón R. and J. M. Barea (2010) Mycorrhizosphere interactions for legume improvement. In: Khanf MS, Zaidi A, Musarrat J, editors. Microbes for Legume Improvement.Vienna: Springer; p. 237-71.

Bardgett, R. D. (2005) The Biology of Soil A Community and Ecosystem Approach. Oxford University Press pp. 242.

Barea J. M., R. Azcón, and C. Azcón Aguilar (2005) Interactions between mycorrhizal fungi and bacteria to improve plant nutrient cycling and soil structure. In: Buscot F, Varma A, editors. Microorganisms in Soils: Roles in Genesis and Functions. Berlin, Heidelberg: Springer-Verlag;.p.195-212.

Barea, J. M. (1991) Vesicular-arbuscular mycorrhizae as modifiers of soil fertility. Adv. Soil Sci. 15:1-40.

Bernier J., G. N. Atlin, R. Serraj, A. Kumar and D. Spaner (2008) Breeding upland rice for drought resistance. J. Sci. Food Agric.; 88: 927-39.

Bozorgi, H. R., F. Tarighi, M. Moradi and E. Azarpour (2011) The study effect of drought stress on four native rice varieties in Iran. World Appl. Sci. J. 13 (3): 410-414.

Duncan, D.B. (1955) Multiple range and multiple F test. Biometrics, 11:1-42.

El-RefaeeI. S., A. E. Abd-El-Wahab and S. A. Ghanem (2005) Physiological performance and yield of some rice cultivars as affected by different irrigation intervals. Egypt J. Agric. Res., 83(58): 393-410.

El-Refaee, I. S., E. E. Gewaily; E. S. Naeem and B. A. Zayed (2011) Water balance and economic evaluation of some Egyptian rice cultivars. J. Agric. Kafer El-Sheikh Univ., 37(1): 85-98.

El-Refaee, I.S., R. N. Gorgy and T. F. Metwally (2012) 
Response of some rice cultivars to plant spacing for improving grain yield and productivity under different irrigation intervals. Alx. J. Agric. Res. 57(1): 1-15.

Garcia de Salamone I, L. Di Salvo, J. Escobar Ortega, P. Boa Sorte, S. Urquiaga andK.Teixeira (2010) Field response of rice paddy crop to Azospirillum inoculation: physiology of rhizosphere bacterial communities and the genetic diversity of endophytic bacteria in different parts of the plants. Plant Soil. 336 (3): 51-62.

Gomez, K. A. and A. A. Gomez (1984) Statistical Procedures for Agricultural Research. 2nd ed. John Wiley Sons, New York, USA.

Jackson, M.L. (1967) Soil Chemical Analysis. Printic Hall of India, New Delhi:144-197.

Kamoshita A., R. C. Babu, N. M. Boopathi and S. Fukai (2008) Phenotypic and genotypic analysis of drought-resistance traits for development of rice cultivars adapted to rainfed environments. Field Crops Res.; 109: 1-23.

Khalvati M., B. Bartha, A. Dupigny and P. Schroder (2010) Arbuscular mycorrhizal association is beneficial for growth and detoxification of xenobiotics of barley under drought stress. J. Soils Sediments 10: 54-64.

Omar, A. M., I. S. El-Refaee, I. A. El-Degwy and Hasnaa, A. Ghazy (2015) Response of rice to plant spacing, organic and mineral fertilization under irrigation regimes. J. Agric. Res. Kakr El-Sheikh Univ., 41(4):1305-1321

Panneerselvam, P., T. Upendra Kumar, C. K. Sugitha, C. Parameswaran, A. Sowarnalisha Sahoo, K. Binodh, A. Jahan, and A. Anandan (2017) Arbuscular Mycorrhizal fungi (AMF) for sustainable rice production. Springer Nature Singapore Pte Ltd. 99126.

Panneerselvam P., B. Saritha, S. Mohandas, K. K. Upreti, S. Poovarasan, V. V. Sulladmath and R. Venugopalan (2013) Effect of mycorrhiza associated bacteria on enhancing colonization and sporulation of Glomus mosseae and growth promotion in sapota (Manilkara achras (mill) Forsberg) seedlings. Biol. Agric. Hortic. 29 (2):118-131.

Rillig M. C. and D. L. Mummey (2006) Mycorrhizas and soil structure. New Phytol 171: 41-53.

RRTC (2012) Rice Research and Training Center
Annual Proceeding for The $11^{\text {th }}$ Nat. Rice Program Workshop 2012, Sakha, Kafer El-Sheikh, Egypt.

Ruiz-Sánchez M, R. Aroca, Y. Muñoz, R. Polón and J. M. Ruiz-Lozano (2010) The arbuscular mycorrhizal symbiosis enhances the photosynthetic efficiency and the antioxidative response of rice plants subjected to drought stress. J. Plant Physiol., 167: 862-869.

Ruiz-Sanchez M., E. Armadab, Y. Munoza, I. E. G. Salamonec, R. Arocab, J. M. Ruiz-Lozanob and R. Azcinb (2017) Azospirillum and arbuscular mycorrhizal colonization enhance rice growth and physiological traits under well-watered and drought conditions. J. of Plant Physiology 168: 1031-1037.

Sahoo S., P. Panneerselvam, T. Chowdhury, A. Kumar, U. Kumar, J. Afrin, S. Ansuman and A. Anandan (2017) Understanding the AM fungal association in flooded rice under elevated $\mathrm{CO}_{2}$ condition. Oryza 54 (3): 290-297.

Sandhu, S. S. and S. S. Mahal. (2014) Performance of rice under different planting methods, nitrogen levels and irrigation schedules. Indian Journal of Agronomy. 5 (3): 392-397.

Secilia J., D. J. Bagyaraj (1994) Evaluation and firstyear field testing of efficient vesiculararbuscular mycorrhizal fungi for inoculation of wetland rice seedlings. World J Microbiol Biotechnol 10 (4): 381-384

Solaiman M. Z. and H. Hirata (1997) Effect of arbuscular mycorrhizal fungi inoculation of rice seedlings at the nursery stage upon performance in the paddy field and greenhouse. Plant Soil 191 (1): 1-12.

Tawaraya, K., M. Naito, and T. Wagatsuma (2006) Solubilization of insoluble inorganic phosphate by hyphalexu - dates of arbuscular mycorrhizal fungi. J. Plant Nutr., 29: 657.

Vivas A, R.Azcón, B. Biró, J. M. Barea, J. M. RuízLozano (2003) Influence of bacterial strains isolated from lead-polluted soil and their interactions with arbuscular mycorrhizae on the growth of Trifolium pratense L. under lead toxicity. Can. J. Microbial. 49: $577-88$.

Zubaer, M. A, A. K. B. Chowdhury; M. Z. Islam. T. Ahmed and M. A. Hasan (2007) Effects of water stress on growth and yield attributes of Aman rice genotypes. Int. J. Sustain. Crop Prod. 2(6): 25-30. 